\title{
Demonstration of Hybrid Castor with Onion as Intercrop under Drip Fertigation System
}

\author{
K. Thirukumaran* and K. Kavitha \\ ICAR-Krishi Vigyan Kendra, Thirupathisaram, Kanyakumari District 629 901, India \\ *Corresponding author
}

\begin{tabular}{l} 
K e y w o r d s \\
Castor, Onion, \\
$\begin{array}{l}\text { Drip irrigation, } \\
\text { Intercrops }\end{array}$ \\
\hline Article Info \\
\hline $\begin{array}{l}\text { Accepted: } \\
18 \text { March } 2020 \\
\text { Available Online: } \\
\text { 10 April } 2020\end{array}$ \\
\hline
\end{tabular}

\section{A B S T R A C T}

To popularize rabi castor cultivation with onion intercrop in drip fertigation in Salem and Namakkal district demonstration were conducted under farmers participatory approach. The castor with onion intercropping through drip fertigation was introduced in different blocks in Namakkal and Salem districts in an area of 18 ha with total beneficiaries of 43 . On observing the yield and economics, the results revealed that the average castor yield of 4 tonnes/ha and onion intercrop yield of 5 tonnes/ha was recorded in the farmer's field and the higher gross return of Rs.2,05,295/ha and net return of Rs.1,54,685/ha and B:C ratio of 3.06 was received with castor + onion intercrop. Introduction of onion as intercrop has given double the return then what they are getting previously other cropping systems with normal irrigation system.

\section{Introduction}

Castor (Ricinus communis L.) belonging to family Euphorbiaceae is one of the ancient oilseed crops of the world. Castor oil is an important industrial oil. In India, Castor crop is grown in an area of 1000 lakh ha, with a production of 1689 lakh tones and productivity of $1689 \mathrm{~kg} / \mathrm{ha}$ (Anonymous, 2015). Gujarat, Andhra Pradesh and Rajasthan are the major castor producing states. India is the largest producer of castor in the world earning nearly Rs.3000 crores of foreign exchange annually through export. Tamil Nadu is an important castor growing state in India, with an area of 13,900 hectare.

Major castor producing districts are Salem, Namakkal, Erode, Dharmapuri and Perambalur. Castor is mostly raised as rainfed crop or intercrop with groundnut in Tamil Nadu and hence the maximum potential yield is not being harnessed. Castor as wider spaced crop is ideal for intercropping system. 
Initially the growth of castor is slower, that period can be effectively harnessed for growing short duration intercrops. Onion is an ideal intercrop for castor; it is short duration and less demanding in terms of water and other inputs.

Castor is drought tolerant crop (Kirloskar, 2007) and water requirement is low $(500 \mathrm{~mm}$ when compared to other crops such as maize $(800 \mathrm{~mm})$ and cotton $(900 \mathrm{~mm})$ which are the major contingent crops (Kaore, 2012). It is suitable for both kharif and rabi season. It grows well for all type of well-drained soil and is good contingent crop for weather aberrations such as delayed monsoon or monsson failure. In the Salem, Namakkal and Erode districts of Tamil Nadu, ground water is over exploited in majority of the blocks. In these three districts the small and marginal farmers constitute 89 per cent of total farmers. Castor is less demanding in terms of land, labour and other inputs, hence it is well suited for the resource poor, small and marginal farmers of these districts. The productivity is low (400 kg/ha), when compared to national average of $1392 \mathrm{~kg} / \mathrm{ha}$. The productivity is low mainly because the castor is cultivated as inter / mixed crop in rainfed eco system. Availability of new productive hybrids such as YRCH 1 and DCH 519 offers a great scope for increasing productivity. There is large gap between realizable potential yield and present productivity in castor. .

In Tamil Nadu important castor growing districts are Salem, Namakkal and Erode. The castor productivity is low mainly because of low spread of hybrid castor as pure crop, Botrytis gery rot in kharif planted crop, Use of low productive traditional land races and local varieties by the farmers, Cultivation as mixed and border crop, Cultivation under rainfed ecosystem in marginal and low fertile soils, Not selecting ideal season (rabi) for cultivation and lack of awareness on agronomic practices fertilizer application, irrigation etc., Irrigation application can be reduced by 50 to 80 per cent with drip irrigation compared to sub surface irrigation and overhead irrigation (Locascio et al., 1989). Under optimum irrigation level, a seed yield of $3780 \mathrm{~kg} \mathrm{ha}^{-1}$ was obtained with the hybrid GCH5 (Raj et al., 2010).

A castor field produced $1774 \mathrm{~kg} /$ ha of seed without irrigation, $2199 \mathrm{~kg} / \mathrm{ha}$ with a supplementary irrigation at the end of the growing season and $4252 \mathrm{~kg} / \mathrm{ha}$ with supplementary irrigation before and after the rainy season (Souza et al., 2007). Through drip fertigation under rabi season, cultivation of castor can increase productivity can to $3500 \mathrm{~kg} / \mathrm{ha}$ which is well above the nation average (1209 kg/ha). Hence drip irrigation system offers a great scope to cultivate castor in these areas. In addition to drip fertigation, onion as intercrop in castor will give additional net income. To popularize rabi castor cultivation with onion intercrop under drip fertigation, demonstration were conducted in Salem and Namakkal under farmers participatory approach.

\section{Materials and Methods}

Farmers having drip system was selected for raising castor with onion intercrop through drip fertigation system during rabi season in consultation. Training on crop production technology of Onion and castor were provided to farmers at village level. Technology of castor + onion intercropping under drip fertigation in rabi season, were covered in all trainings.

Improved Castor Hybrid YRCH 1 with Onion CO5 as inter crop was demonstrated under drip fertigation. A total of ten demonstrations per block were conducted by selecting the farmers who is already having the drip fertigation system in their fields. Field days 
were conducted in the farmers holdings to disseminate the technology of raising castor + onion intercrop under drip fertigation. Totally ten field days were conducted at the rate of one field day per block.

\section{Results and Discussion}

The castor with onion intercropping through drip fertigation was newly introduced in different blocks in Namakkal and Salem districts in an area of 18 ha with total beneficiaries of 43. On observing the yield and economics, the results revealed that the average yield of 4 tons/ha was recorded in the farmers field and the higher gross return of Rs.196530/ha and net return of Rs.145920/ha and $\mathrm{B}: \mathrm{C}$ ration of 2.89 (Table 1). The results are similar to the finding of Padmaiah et al., 2012 and Kumar Naik et al., (2015). Results are similar to the finding of Babu GS, 2014 that intercropping of onion in the wider spaced rabi castor was found to be more remunerative and beneficial with better growth and yield of both the crops. The effect of drip fertigation on growth and yield of castor + onion intercropping system was reported earlier by Pushpanathan et al., (2017). Introduction of Onion as a new crop under intercropping system double the return then what they are getting previously. In future the area under this crop may be increased due to impact of the area and the returns realized.

Table.1 Economic Impact of Demonstrations on castor with onion intercrop under drip fertigation

\begin{tabular}{|c|c|c|c|c|c|c|c|c|}
\hline \multirow[t]{2}{*}{ S.No } & \multirow[t]{2}{*}{ Block } & \multirow[t]{2}{*}{$\mathrm{COC}$} & \multicolumn{2}{|c|}{ Yield (kg/ha) } & \multirow{2}{*}{$\begin{array}{c}\text { Gross } \\
\text { Income/ha }\end{array}$} & \multirow{2}{*}{$\begin{array}{c}\text { Net } \\
\text { income/ha }\end{array}$} & \multirow[t]{2}{*}{ BCR } & \multirow{2}{*}{$\begin{array}{c}\text { BCR } \\
\text { Farmers } \\
\text { practice }\end{array}$} \\
\hline & & & Castor & Onion & & & & \\
\hline 1. & Namagiripetti & 50610 & 3895 & 5276 & 199631 & 149021 & 2.95 & 1.98 \\
\hline 2. & Rasipuram & 50610 & 3788 & 5382 & 197153 & 146543 & 2.90 & 1.83 \\
\hline 3. & Elachipalayam & 50610 & 3737 & 5389 & 195445 & 144834 & 2.86 & 1.92 \\
\hline 4. & Trichendodu & 50610 & 3680 & 5026 & 189096 & 138486 & 2.74 & 1.79 \\
\hline 5. & Edapadi & 50610 & 3786 & 5511 & 198643 & 148033 & 2.93 & 1.99 \\
\hline 6. & Valapdi & 50610 & 3742 & 5467 & 196574 & 145964 & 2.89 & 1.94 \\
\hline 7. & Mecheri & 50610 & 3879 & 5401 & 200116 & 149506 & 2.95 & 1.88 \\
\hline 8. & Omalur & 50610 & 3715 & 5508 & 196105 & 145495 & 2.88 & 1.67 \\
\hline 9. & Pudhuchatram & 50610 & 3759 & 5352 & 195772 & 145162 & 2.87 & 1.90 \\
\hline \multirow[t]{2}{*}{10.} & Sankagri & 50610 & 3761 & 5428 & 196764 & 146154 & 2.89 & 1.86 \\
\hline & \multicolumn{2}{|c|}{ Average } & 3774 & 5374 & 196530 & 145920 & 2.89 & 1.87 \\
\hline
\end{tabular}




\section{Outcome}

The area and productivity of hybrid castor has been increased.

Hybrid castor cultivation was popularized among the farmers against local variety / races.

Castor hybrid area was increased to a tune of $20 \%$ in the current year itself that too as pure crop cultivation.

By introduction of drip fertigation technology, the yield was increased by $1500 \mathrm{~kg} / \mathrm{acre}$ as against $1000 \mathrm{~kg} / \mathrm{ac}$ in normal irrigated cultivation.

Introduction of onion intercrop in castor realized an additional income of Rs.20,000/- per acre.

Farmers realized a net income of Rs. 50,000 per acre in drip fetigation for castor - onion intercropping technology against Rs. 25,000$30,000 /$ acre in castor pure crop alone. By cultivation of local variety / races the farmer will get only Rs.10,000.

\section{References}

Anonymous. (2015). Annual Castor Report. Indian Institute Of Oilseeds Research, Hyderbad-500 030.

Babu GS, 2014 Feasibility of wider spaced rabi castor with intercropping of vegetables under south Gujarat condition. PhD Thesis submitted to N.M. College of agriculture, Navsari Agricultural University, Navsari pp154

Kaore, S.V. (2012). Integrated plant nutrition system on farmers' field. Fert. News, 47 (2): 61-63.
Kirloskar, S. (2007). Manage water to enrich lives. Second India-ASEAN Summit2003, New Delhi, India.

Kumar Naik, A.H., Umamaheswarappa, P and Hanumantha Naik, G (2015) Economic Impact of Front Line Demonstrations on Castor (Ricinus communis L.) in Chitradurga districts of Karnataka Journal of Agriculture and Veterinary Science 8 (8)-90-94

Locascio, S.J., Olson, S.M. and Rhoads, F.M. (1989). Water quantity and time of $\mathrm{N}$ and $\mathrm{K}$ application for trickle-irrigated tomatoes. J. Amer. Soc. Hort. Sci., 114: $265-268$

Padmaiah, M., Venkatkumar, R., Iswar Singh, S., Solanki And Sarad, C. (2012). Castor (Ricinus communis L.) frontline demonstrations in jodhapur District of Rajasthan: An Impact Study. J. Oilseeds Research., 29 (1): 84-88

Pushpanathan, K. R., Pandian, B. J., Mariappan, G. and Jeyakumar, P. (2017). Effect of drip fertigation on growth and yield of castor + onion intercropping system. Agric. Update, 12 (TECHSEAR-4):1099-1104

Raj, A.D., Patel, B.S. and Mehta, R.S. (2010). Effect of irrigation methods on growth and economics of hybrid varieties of castor. Indian J. Agric. Sci., 80: 795 800

Souza, A.S., Tavora, F. J.A.F., Pitombeiria, J. B. and Bezerra, F.M. I. (2007). Planting time and irrigation management for castor plant and its effect on growth and productivity. Rev. Cienc. Agronomica. 38: $422-429$

\section{How to cite this article:}

Thirukumaran, K. and Kavitha, K. 2020. Demonstration of Hybrid Castor with Onion as Intercrop under Drip Fertigation System. Int.J.Curr.Microbiol.App.Sci. 9(04): 2500-2503. doi: https://doi.org/10.20546/ijcmas.2020.904.299 